\title{
Para uma ontologia crítica do Estado e da política: um debate entre Clastres e Marx
}

Rômulo André Lima'

\section{Resumo}

O artigo analisa os principais elementos da compreensão do etnólogo Pierre Clastres sobre a esfera política na tentativa de reforçar uma perspectiva crítica sobre o Estado, entendendo que o cotejamento de sua teoria com o pensamento marxiano é frutífero tanto para uma etnologia das relações políticas como para o desenvolvimento de uma adequada teoria marxista do Estado. A análise parte da identificação de uma a concepção ontonegativa do Estado presente nas considerações de Clastres e na teoria social de Marx. O trabalho do último Lukács é tomado como referência, especialmente nos momentos em que o autor, investigando as categorias fundantes do ser social, evidencia e desenvolve os elementos próprios de uma ontologia materialista.

Palavras-chave: Estado. Economia. Ontologia.

\section{Introdução}

O percurso teórico de Marx é marcado, nos chamados textos de juventude, por uma progressiva aproximação com relação às categorias que, delineadas ao longo do seu amadurecimento intelectual, fundariam a base da sua teoria social. Ainda que o estudo aprofundado da Economia Política só se dê com os Manuscritos econômico-filosóficos de 1844, percebe-se, já no período entre 1843 e1844, uma tomada de posição decisiva para a concepção materialista do autor. É, então, que Marx rompe claramente com a concepçáo de "[...] politicidade como atributo perene, positivamente indissociável da autêntica entificação humana, portanto constitutiva do gênero, de sorte que orgânica e essencial em todas as suas atualizaçóes." (CHASIN, 1995, p. 354).

Doutorando em Economia pela Universidade Federal Fluminense (UFF). Niterói, Rio de Janeiro, Brasil. É autor de artigos publicados nas revistas Margem Esquerda (2012). Revista da Sociedade Brasileira de Economia Politica, (201I) e Leituras de Economia Política (Unicamp - 2010). E-mail: romuloandrelima@yahoo.com. 0 autor agradece a André Guimarães Augusto os comentários que enriqueceram o texto. 
O caráter ontopositivo da política, que consiste em considerar a politicidade como elemento ineliminável da constituiçáo ontológica do ser social portanto, como atributo imanente e definidor desse ser -, permeava os herdeiros do hegelianismo, implicando a abordagem dos problemas sociais de forma a resolvê-los sempre com vistas à suposta universalidade racional do Estado.

A superação dessa posição aponta, no jovem Marx, para a compreensáo de que é na esfera da sociedade civil ${ }^{2}$ que estáo contidos os elementos definidores do metabolismo da sociedade burguesa. $\mathrm{O}$ passo seguinte no percurso teórico do autor será buscar as categorias econômicas que explicam o funcionamento geral do modo de produçáo capitalista.

No que diz respeito ao Estado, a compreensáo ontonegativa da política demonstra, desde entáo, o caráter radical da crítica de Marx ao poder estatal, que se destaca, ao seu olhar, como uma entidade estranha à própria sociedade que a engendrou. $\mathrm{O}$ Estado, portanto, longe de ser uma instituição que realiza o próprio gênero humano, no que diz respeito à sua existência social, aparece como um poder estranhado, como um obstáculo à organizaçáo das potências sociais na forma de uma ordem diretamente social.

Uma visão ontonegativa do Estado, posição pouco comum nas ciências sociais, também foi desenvolvida por Clastres $^{3}$, cujas constataçóes sobre as sociedades primitivas e a origem do Estado, entretanto, sáo apresentadas usualmente em oposiçáo à visáo marxista. Uma leitura atenta de seus textos, entretanto, mostra que sua crítica à antropologia marxista é, em certos aspectos, próxima da visáo original de Marx, ainda que divergente em pontos que, naturalmente, merecem destaque.

$\mathrm{O}$ presente artigo analisa os principais elementos da compreensão de Clastres sobre a esfera política na tentativa de reforçar uma perspectiva crítica sobre o Estado, entendendo que o cotejamento com o pensamento marxiano é frutífero tanto para as bases de sua etnologia como para o desenvolvimento de uma adequada teoria marxista do Estado. Para tanto, será tomado como

2 Entendida como a esfera que abarca o "[...] conjunto do intercâmbio material dos individuos no interior de um estágio determinado das forças produtivas." (MARX; ENGELS, 2007, p. 74).

3 Pierre Clastres (1934-1977), etnólogo francês dedicado especialmente ao estudo das sociedades primitivas na América do Sul. Crítico do estruturalismo e do formalismo, o autor, morto prematuramente, escreveu $A$ sociedade contra o Estado (1990 [1974]), seu trabalho mais divulgado. 
base o trabalho de Lukács (1979a; 2010) que, ao investigar as categorias fundantes do ser social, evidencia e desenvolve os elementos próprios de uma ontologia materialista.

\section{A sociedade contra o Estado}

A princípio, pode parecer fora de propósito comparar criticamente duas teorias sobre o Estado que versam sobre momentos táo díspares. Afinal, Clastres dedicou-se ao estudo das sociedades primitivas; Marx, ao capitalismo. Clastres investigou a lógica social das sociedades sem Estado; Marx, a da sociedade burguesa com avançado desenvolvimento do aparelho estatal. E, ainda, náo se pode desprezar o fato de que ambos náo chegaram a sistematizar, em suas obras, uma teoria geral sobre o Estado.

Não obstante, assim como na obra marxiana, é possível identificar, no trabalho de Clastres, os fundamentos de uma concepçáo própria sobre a esfera política e sobre o Estado. Mesmo dedicando-se ao estudo das sociedades sem Estado, a preocupaçáo teórica com o surgimento dessa entidade está no centro da análise desse autor. Assim, apesar de náo discorrer sobre as sociedades mais complexas, Clastres analisa os elementos fundamentais da organizaçáo política e, ao mirar a gênese do Estado, aponta para a constituiçáo ontológica desse campo da prática e sua relaçáo com as demais esferas da sociabilidade humana ${ }^{4}$.

Com o intuito de formular uma compreensão mais adequada sobre as faculdades sociais do homem, Clastres propóe-se a desmistificar a visáo corrente no campo da antropologia sobre as condiçóes materiais supostamente precárias das sociedades primitivas 5 . $\mathrm{O}$ autor póe em questáo a própria definiçáo dessas sociedades como "economias de subsistência". Clastres argumenta que o termo economia de subsistência traz escondido um juízo de valor que impede o conhecimento real dessas comunidades: sociedades primitivas seriam aquelas

4 Como afirma o próprio autor, referindo-se ao estudo das sociedades primitivas: "Não se trata simplesmente de um problema 'interessante', de um tema reservado apenas à reflexão dos especialistas, pois a Etnologia ganha as dimensões de uma teoria geral (a construir) da sociedade e da história." (CLASTRES, 1990 [1974], p. 139).

50 que se chama aqui "sociedades primitivas" (e que constitui o objeto de análise de Clastres) compreende não o homem pré-histórico, mas os grupamentos humanos que permaneceram relativamente fechados em sua lógica mesmo após o desenvolvimento de formas sociais mais complexas. Trata-se das comunidades observadas desde séculos por viajantes, exploradores, missionários e antropólogos. $O$ isolamento e o caráter relativamente conservador dessas culturas permitem que a reflexão seja tomada como referência generalizável no que diz respeito ao desenvolvimento ontológico da socialidade humana. 
que ainda não desenvolveram um sistema dinâmico de produçáo e de trocas, que ainda náo desenvolveram o mercado. Sociedades definidas por aquilo que supostamente lhes falta, compreendidas como estágios primitivos de um desenvolvimento superior necessário e, em maior ou menor grau, linear. Dizê-las de subsistência, assim, implica entendê-las com base em uma lógica estranha a elas mesmas, com o que fica impedido o reconhecimento, nessas sociedades, de um mecanismo particular de reprodução. Estudo eminentemente anti-histórico e mistificador, já que a lógica das sociedades produtoras de excedentes é imposta como referência para definir um momento radicalmente heterogêneo do desenvolvimento social. "E, a fim de explicar essa incapacidade das sociedades primitivas de sair da estagnaçáo de viver o dia-a-dia, dessa alienaçáo permanente na busca de alimentos, invocam-se o subequipamento técnico, a inferioridade tecnológica." (CLATRES, 1990 [1974], p. 133).

Utilizar a inferioridade técnica como chave para compreender o sistema social dessas comunidades é, novamente, reduzi-las a um ponto na linha de desenvolvimento que conduz à sociedade industrial, o que, além de tornar mais obscura a própria dinâmica das sociedades modernas, assume implícita ou explicitamente um determinismo de tipo econômico. De acordo com essa visão, o desenvolvimento tecnológico, naturalmente, conduziria a sociedade para a formaçáo de uma economia produtora de excedentes, instaurando uma economia de trocas ou economia de mercado - ponto culminante da "evoluçáo" social. Com isso, no entanto, fica suprimida a pergunta essencial: como o desenvolvimento tecnológico se expressa na lógica particular dessa formaçáo social "primitiva"? Pergunta que pode ser colocada de outra forma: todo desenvolvimento tecnológico conduz, necessariamente, a sociedades estratificadas?

Contra a visáo determinista e teleológica implícita nesse conceito de economias de subsistência, Clastres propóe uma análise que ressalta a diferença específica dessas comunidades: em vez de permanentemente mobilizadas para a produçáo, por tecnicamente inferiores que seriam, as sociedades primitivas são caracterizadas pelo esforço mínimo para obtençáo dos produtos tidos como necessários. Longe de sobreviver graças ao esforço constante dos indivíduos, elas dedicam relativamente pouco tempo "àquilo a que damos o nome de trabalho" (CLASTRES, 1990 [1974], p. 135).

Afinal, por que esses indivíduos haveriam de trabalhar mais que o suficiente para suprir as necessidades que a sociedade se póe? Em outras palavras, por que essas sociedades deveriam produzir excedentes? A evidente 
superioridade do machado de metal sobre o de madeira não representava, para os índios, a possibilidade de produzir dez vezes mais, digamos, no mesmo espaço de tempo; ao contrário, com a nova ferramenta, eles poderiam produzir a mesma coisa dez vezes mais rápido. E, com isso, o tempo dedicado a outras atividades se ampliaria.

As sociedades primitivas não são sociedades do trabalho justamente pelo fato de que o trabalho não assume uma dimensão autônoma na vida social. Tampouco a economia dessas sociedades, afirma Clastres, existe como esfera autônoma. O trabalho não é fonte de diferenciação entre os indivíduos, já que "[...] a produção é projetada sobre a reconstituição do estoque de energia gasto. Em outros termos, é a vida como natureza que [...] fundamenta e determina a quantidade de tempo dedicado a reproduzi-la." (CLASTRES, 1990 [1974], p. 138).

As sociedades primitivas dispóem de todo o tempo necessário para expandir sua produção. Se assim não o fazem não é por incapacidade técnica, mas por náo existir nenhuma determinaçáo externa à reproduçáo de suas necessidades imediatas que lhes imponha o sobretrabalho. O excesso, quando há, figura como produçáo suplementar, utilizado em festas e como estoque para o futuro - ou seja, não deixa de estar incluído no tempo "normal" de trabalho. A atividade de produçáo é medida pelas necessidades que têm de ser satisfeitas, "[...] estando implícito [...]", afirma Clastres, "[...] que se trata essencialmente das necessidades energéticas” (CLASTRES, 1990 [1974], p. 138).

Inacabamento, incompletude, falta: não é absolutamente desse lado que se revela a natureza das sociedades primitivas. Ela impõe-se bem mais como positividade, como domínio do meio ambiente natural e do projeto social, como vontade livre de não deixar escapar para fora do ser nada daquilo que possa alterá-lo, corrompê-lo e dissolvê-lo (CLASTRES, 1990 [1974], p. 139).

Caracterizadas não pela ausência do excedente (ou do mercado), mas pela positividade do controle imediato da reprodução ${ }^{6}$, as sociedades primitivas só

6 A caracterização do controle direto da produção por parte das sociedades primitivas esbarra no aspecto profundamente místico que cerca essas culturas. Não obstante, a imediaticidade da produção é compreendida como a ausência de mediação entre a produção e a satisfação das necessidades, mediação que assume caráter determinante no caso das sociedades que produzem para o mercado. "Na sociedade primitiva, [...] os homens são senhores de sua atividade, senhores da circulação dos produtos dessa atividade: [...] mesmo se a lei de troca dos bens medeia a relação direta do homem com o seu produto." (CLASTRES, 1990 [1974], p. 138). 
perdem o autocontrole de suas capacidades produtivas quando alguma instância se destaca do conjunto e se apresenta com capacidade para exigir uma produçáo maior. "Tudo se desarruma [...] quando a atividade de produçáo se afasta do seu objetivo inicial, quando, em vez de produzir apenas para si mesmo, o homem primitivo produz também para os outros, sem troca e sem reciprocidade. Só então é que podemos falar em trabalho." (CLASTRES, 1990 [1974], p. 138).

Tem-se, entáo, a autonomizaçáo de duas esferas antes diluídas no interior da prática social: a economia e a política. Como observa Clastres, "é ali que se inscreve a diferença entre o selvagem amazônico e o índio do Império Inca. O primeiro produz, em suma, para viver, enquanto o segundo trabalha, de mais a mais, para fazer com que os outros vivam" (CLASTRES, 1990 [1974], p. 138). É exatamente aí, no surgimento do trabalho alienado, que, para Clastres, a sociedade deixa de ser primitiva. "Os selvagens produzem para viver, eles não vivem para produzir.” (CLASTRES, 1976, p. 18).

Ora, uma dinâmica capaz de impor aos indivíduos o sobretrabalho depende da capacidade de coerção, do exercício do poder político. É, portanto, somente quando se instaura a divisáo entre senhores e súditos que surge a separação entre produtores e apropriadores, afirma Clastres. Quando a sociedade primitiva permite a autonomizaçáo da política, esta se converte em uma instância que regula a sociedade com base na sua própria intencionalidade. Com isso, uma parte da sociedade ganha vontade própria. Vontade que, uma vez legitimada - geralmente pela força - submete o restante da comunidade aos seus próprios desígnios. "Deter o poder e impor o tributo constituem um momento único, e o primeiro ato do déspota consiste em proclamar a obrigação de pagar." (CLASTRES, 1976, p. 26). Ou seja, a primeira manifestaçáo do poder de sujeitar é a imposição do trabalho alienado, que náo atende mais apenas às necessidades do indivíduo produtor, mas também às do apropriador.

Dessa forma, a existência do Estado torna-se a linha divisória entre dois tipos de formaçáo social: sociedades primitivas (ou sociedades sem Estado), de um lado, e sociedades com Estado, de outro. Clastres observa que a recusa à autonomizaçáo da economia é a outra face da recusa à politizaçáo da economia (ou seja, ao uso da economia de acordo com fins políticos impostos pelo Estado) - consequência da autonomização da própria política. É, portanto, a recusa ao poder político separado que define a sociedade primitiva. 
Sociedade sem Estado, sociedade sem classes: assim a antropologia anuncia as determinações que fazem com que uma sociedade possa ser dita primitiva. Sociedade, portanto, sem órgão separado de poder político, sociedade que impede, de maneira deliberada, a divisão do corpo social em grupos desiguais e opostos (CLASTRES, 1976, p. 20).

Mas, se a sociedade primitiva se reproduz de acordo com sua própria legalidade imanente, sem excedentes e sem trabalho alienado, como pode surgir uma nova determinação capaz de subjugá-la? Em outras palavras, como uma sociedade sem Estado se converte em uma sociedade com Estado? Aparte uma situaçáo de violência externa e consequente dominaçáo por outra comunidade, é a instituição do chefe, segundo Clastres, que parece concentrar as maiores possibilidades de surgimento de uma figura mínima de Estado. Mas, bem observado, ao chefe das comunidades primitivas é interditado o acesso ao poder. Antes de controlar a sociedade, é a sociedade que o controla. Ele náo recebe poder, mas, antes, o prestígio para intermediar conflitos e reafirmar a unidade da tribo.

O chefe nunca assume uma posiçáo acima da sociedade, pois está sempre em divida com ela. Em troca do prestígio que a sociedade lhe confere, ele deve oferecer seus serviços. Assim, ele é apenas um meio para a sociedade, que permanece como verdadeiro lugar do poder (náo alienado). Sempre que o desejo de poder do chefe excede os limites da instituição, a sociedade volta a negá-lo a possibilidade de tornar-se ela mesma um meio para os fins particulares do chefe. É assim que a sociedade preserva a si mesma da separação do poder político, do surgimento do Estado, continuando, com isso, a se reproduzir dentro de sua lógica.

Mas existem, contudo, situaçóes de exceçáo em que o fluxo de poder da sociedade sobre o chefe pode ser invertido. A guerra é uma atividade que exorta o chefe a exercer um comando mais abrangente (no tempo e no espaço) sobre a comunidade. Mas, quando a guerra termina, entretanto, o chefe continua sendo chefe, já que a decisão pelo conflito náo partiu dele, e sim da sociedade. Esta não lhe concede poder como retribuiçáo pela vitória, mas apenas o prestígio que cabe ao chefe. De toda forma, um chefe cujo prestígio depende do êxito militar é impelido a renovar as circunstâncias da guerra, a fim de sustentar o reconhecimento recebido da sociedade. "Alterando a relaçáo normal que determina o líder como meio ao serviço de um fim socialmente definido, ele tenta fazer da sociedade o meio de realizar um fim puramente privado [...]. Mas isso nunca funciona" (CLASTRES, 1990 [1974], p. 145-146, grifo nosso). 
A constância da guerra ensejaria a consolidaçáo da autoridade do líder, do chefe que, cercado de um grupo que lhe apóia (normalmente outros guerreiros em busca de prestígio), tornar-se-ia governante. Surgiria, entâo, o Estado e seria invertida a lógica anterior: a sociedade agora estaria a serviço do chefe. Haveria, entáo, dominantes e dominados. Para Clastres (1990 [1974]), porém, isso nunca acontece. Segundo o autor, a sociedade primitiva evita, a todo custo, o surgimento do Estado, e as tentativas individuais de assumir o poder náo encontram ressonância em uma "[...] sociedade à qual nada escapa, que nada deixa sair de si mesma." (CLASTRES, 1990 [1974], p. 148). Essas sociedades tendem a se reproduzir eternamente como tal. Assim, apenas uma contradiçáo interna à sua própria lógica pode romper com a negativa peremptória ao surgimento do Estado.

Clastres (1990 [1974]) não é conclusivo em sua análise, mas aponta para a possibilidade de emergência do Estado justamente como consequência de sua negaçáo, ou seja, de sua reproduçáo tal qual sociedade sem Estado. Citando o exemplo dos tupis-guaranis, o autor reconhece, na liderança dos profetas, a capacidade de resistir ao crescimento do poder dos chefes guerreiros. Apoiados na palavra, os profetas guiam a sociedade primitiva em fuga contra o Estado e, com isso, acabam configurando, em torno de si mesmos, um poder de comando, um poder germinal de Estado.

\section{Desenvolvimento e prioridade: um contraponto com a ontologia marxiana}

$\mathrm{Na}$ busca por reconhecer a forma social típica das sociedades primitivas, Clastres (1990 [1974]) aponta para um aspecto-chave na compreensão dos processos históricos: o desenvolvimento da sociabilidade só pode ser compreendido como uma trajetória marcada por rupturas, por descontinuidades. Em cada momento de seu desenvolvimento, a humanidade configurou-se como formas sociais específicas, erguendo-se com base em lógicas particulares.

"Todos os povos policiados foram selvagens", escreve Raynal. Mas o registro de uma evolução evidente de forma alguma fundamenta uma doutrina que, relacionando arbitrariamente o estado de civilização com a civilização do Estado, designa este último como termo necessário atribuído a toda sociedade (CLASTRES, 1990 [1974], p. 133).

Evitando a definição das sociedades primitivas pela ausência (de excedente, de trocas ou de Estado), Clastres náo faz delas uma simples etapa 
obstruída de desenvolvimento para a sociedade de troca e com Estado, como se esta fosse a trajetória natural das formas sociais. Assim, deixa-se de procurar o que supostamente lhes falta, deixa-se de conjeturar sobre os impedimentos (técnicos) para o que seria o pleno desabrochar da autêntica natureza humana. Com isso, Clastres desnaturaliza a lógica da produção de excedentes como um atributo imanente à vida social.

Ao desenvolver uma concepçáo que se pretende orgânica sobre o todo social, Clastres aproxima-se consideravelmente da perspectiva marxiana. A articulaçáo da política e da economia como momentos de uma totalidade complexa e a rejeiçáo de uma visáo compartimentada do social permitem ao autor compreender como uma legalidade histórica a lógica específica de uma determinada formação social - no caso, das sociedades primitivas. Por legalidade histórica, compreende-se o conjunto de determinaçóes estruturais que facultam e condicionam o agir humano num dado momento do desenvolvimento histórico de uma sociedade.

É evidente que, na análise de Clastres, o excedente é indissociável do poder político. A partir disso, já seria possível reconhecer que, em Clastres, economia e política fazem parte de um mesmo todo determinado de modo reflexivo. No entanto, a relaçáo entre essas duas esferas, do ponto de vista de uma organicidade coerente do sistema, torna-se problemática, uma vez que a questão da prioridade ontológica entre os dois momentos complementares não é satisfatoriamente compreendida pelo autor. $\mathrm{O}$ que nos faz observar que, apesar das críticas coerentemente dirigidas contra um materialismo vulgar entâo vigente na antropologia, Clastres passa ao largo de aspectos importantes do pensamento de Marx. O etnólogo reconhece a distância que separa Marx dos antropólogos marxistas por ele criticados, mas não retira disso os elementos que poderiam enriquecer sua própria teoria ${ }^{7}$. Antes de aprofundar essa observação, é válido recolher alguns pontos centrais da análise clastriana sob a ótica das categorias marxianas.

Quando Clastres afirma que, nas sociedades primitivas, o econômico não se constitui como esfera autônoma, toca no elemento fundamental da

7 No prefácio ao liuro Âge de pierre, âge d'abondance, de Marshall Sahlins, Clastres (1976, p. 28) comenta: "Bem mais que o marxismo de Marx, trata-se aqui, que seja bem entendido, do marxismo daqueles pelos quais Marx não escondia seu desprezo. [...] Epígonos sem talento, os marxistas contemporâneos proclamam confiantemente que seus pensamento (!) não tem nada a ver com o marxismo vulgar'. O deles será assim tão distinto?". 
distinção feita por Marx entre o capitalismo e as formas sociais anteriores. Clastres faz isso para rejeitar uma historicidade linear que define as sociedades primitivas como economias de subsistência. Assim, o autor pode estabelecer a diferença específica dessas comunidades.

Como se viu, para Clastres, náo é por incapacidade técnica que essas sociedades náo produzem mais, mas porque, na lógica social que as orienta, o excedente simplesmente náo se define, uma vez que toda a produçáo é diretamente voltada para a satisfaçáo das necessidades da comunidade sem mediaçáo por nenhuma esfera autônoma. Com isso, o próprio trabalho, como valor social autodefinido, náo existe para os indivíduos. "Nas sociedades primitivas, a economia não é uma 'máquina' de funcionamento autônomo: é impossível separá-la da vida social, religiosa, ritualística etc." (CLASTRES, 1976, p. 28-29).

Outro ponto importante no argumento de Clastres é o caráter transistórico da reduçáo do tempo de produção social, que pode ser contrastado com o caráter historicamente determinado da economia de trabalho como valor econômico-social do capitalismo. No primeiro caso, reconhecido pelo autor no âmbito das sociedades primitivas, fica claro que toda e qualquer sociedade, podendo diminuir o tempo dedicado à produção material, assim o fará, mas não para produzir mais. Em vez disso, trabalha-se menos e, com o tempo poupado, pode dedicar-se a outras atividades. É a universal preferência pelo menor esforço - o que náo significa menor qualidade.

No caso da sociedade capitalista, por outro lado, a economia de tempo nunca se traduz em menos trabalho para o produtor, mas em mais sobretrabalho, fonte do excedente, do mais-valor. É o que afirma Marx quando se refere à introdução da maquinaria na indústria moderna: "A maquinaria mais desenvolvida força o trabalhador a trabalhar mais tempo que o selvagem ou que trabalharia esse mesmo trabalhador com ferramentas mais simples e toscas." (MARX, 2009, p. 232).

Se a atividade produtiva náo tem outro objetivo senáo o de satisfazer, diretamente, as necessidades postas pela comunidade enquanto corpo social, o que se chama de excedente é apenas a parte da produçáo normal que suplanta ocasionalmente o satisfatório, compondo o tempo normal de trabalho. Assim, uma sociedade em que não existe excedente não pode estar dividida 
em classes. E o Estado, regulador da vida social que depende logicamente da existência de uma classe produtora e de outra apropriadora, também náo se define. Afinal, "sendo ou náo verdade que o objetivo essencial do Estado seja manter a exploração, o seu cumprimento das funçóes sociais implica uma divisão social do trabalho e a apropriaçáo por alguns grupos sociais de excedentes produzidos por outros" (WOOD, 2003, p. 37).

É, portanto, uma transformaçáo operada na lógica social como um todo que faz emergir esferas autônomas no todo social: o político, na forma (ainda que rudimentar) do Estado, e o econômico, uma vez que o excedente passa a ser (ao menos uma) finalidade da produção. Desse ponto de vista, para Clastres, a transformaçáo política ocorre em paralelo a uma mudança econômica, com as esferas movimentando-se, aparentemente, numa relação orgânica.

Surge, no entanto, conforme antecipado, um problema importante quando Clastres tenta estabelecer uma relação de prioridade da esfera política sobre a econômica. Ao se deter sobre a transformaçáo operada pelo surgimento do Estado, o autor afirma:

A principal divisão da sociedade, aquela que serve de base a todas as outras, inclusive sem dúvida a divisão do trabalho, é a nova disposição vertical entre a base e o cume, é o grande corte político entre detentores da força, seja ela guerreira ou religiosa, e sujeitados a essa força. A relação política de poder precede e fundamenta a relação econômica de exploração. Antes de ser econômica, a alienação é política, o poder antecede o trabalho, o econômico é uma derivação do político, a emergência do Estado determina o aparecimento das classes (CLASTRES, 1990 [1974], p. 138-139).

Depois de reconhecer que a economia náo existe como campo autônomo nas sociedades primitivas e de argumentar que apenas uma nova conformaçáo política pode fazer surgir o excedente, Clastres prossegue o raciocínio afirmando que é o político que detém prioridade última na determinação dessa lógica social. Percebe-se aí que um tratamento mais detido sobre o significado da prioridade de uma esfera sobre outra, na totalidade complexa da realidade social, poderia conduzir Clastres a uma interpretaçáo mais aprofundada sobre o complexo de problemas em questáo. Dizer que a economia é a esfera, o momento ou o complexo predominante náo quer dizer que seja ela a esfera que direta e exclusivamente dirige a reproduçáo social. Uma sociedade onde o excedente é extraído de forma extraeconômica - onde, portanto, a economia náo desponta como esfera autônoma, sujeita que está às determinaçóes 
políticas - expressa, ainda assim, a prioridade objetiva da economia. A esfera econômica é, assim, ontologicamente predominante pela própria materialidade do ser social, que depende, primariamente, da produção e reprodução de suas condiçóes materiais de existência.

Quando atribuímos uma prioridade ontológica a determinada categoria com relação a outra, entendemos simplesmente o seguinte: a primeira pode existir sem a segunda, enquanto o inverso é ontologicamente impossível. [...] O mesmo vale, no plano ontológico, para a prioridade da produção e da reprodução do ser humano em relação a outras funções. Quando Engels, no discurso pronunciado junto à tumba de Marx, fala do "fato elementar [...] de que os homens devem primeiro de tudo comer, beber, ter um teto e vestir-se, antes de ocupar-se de política, de ciência, de arte, de religião etc.", está falando precisamente de uma relação de prioridade ontológica (LUKÁCS, 1979a, p. 4I).

Ainda que, em formaçóes sociais que precedem o capitalismo, a extraçáo do excedente se dê por meio da coerção política explícita e direta, a economia, o modo específico de produção e reprodução material da sociedade, continua sendo o momento fundamental, sem o qual os demais complexos náo podem existir. É precisamente nisso que consiste a prioridade ontológica.

Clastres tenta demonstrar que só faz sentido falar em excedente, em exploraçáo, quando uma parte da sociedade consegue se impor sobre a outra, quando, dessa forma, a dominaçáo política se instaura. Sem a pressão política, sem a obrigação imposta pelo Estado, o excedente não se define. No nível da prioridade ontológica, no entanto, deve-se argumentar que, sem que a produção de excedentes seja tecnicamente possível, é impossível que haja Estado. Pois é claro que o homem precisa satisfazer suas necessidades antes de poder satisfazer, continuamente, as de outro indivíduo.

Se o trabalhador precisa de todo seu tempo para produzir os meios de subsistência necessários ao sustento de si mesmo e de sua race, não lhe resta tempo algum para trabalhar gratuitamente para uma terceira pessoa. Sem certo grau de produtividade do trabalho não há tal tempo disponível para o trabalhador, e sem tal tempo excedente, nenhum mais-trabalho e, portanto, nenhum capitalista, mas também nenhum senhor de escravos, nenhum barão feudal, em uma palavra, nenhuma classe de grandes proprietários (MARX, 1996, p. 140).

O excedente só pode existir quando o homem consegue produzir mais do que necessita para sobreviver, permitindo, assim, que outros sobrevivam do 
seu trabalho. Isso não significa que a possibilidade do excedente se converta, automaticamente, em necessidade, nem que as sociedades primitivas devam ser tomadas como sociedades materialmente miseráveis. Aliás, a pobreza só se define em sociedades estratificadas, ou melhor, que produzem a estratificaçáo.

O produtor direto precisa I) possuir força de trabalho suficiente e 2) as condições naturais de seu trabalho, portanto, em primeira instância o solo a ser trabalhado, devem ser suficientemente férteis, numa palavra, a produtividade natural de seu trabalho precisa ser suficientemente grande para que lhe reste a possibilidade de trabalho excedente, acima do trabalho necessário à satisfação de suas necessidades imprescindíveis. Essa possibilidade não cria a renda: isso só ocorre pela coerção, que faz da possibilidade uma realidade (MARX, 1985, p. 252, grifo nosso).

Por isso, ainda que o efetivo surgimento das classes implique uma transformaçáo de cunho eminentemente político, as condiçóes materiais precisam estar postas para que haja diferenciaçáo de classes. A economia, dessa forma, náo pode deixar de ser ontologicamente predominante. Ou seja, correçáo a ser feita diz respeito à necessidade de uma estrutura econômica compatível com a transformação política que instaura a divisão analisada por Clastres entre sociedade e Estado.

\section{A complexidade do processo histórico-social}

Como observado, a crítica ao materialismo mecanicista (por pretender derivar a superestrutura jurídico-política diretamente da base econômica) é relativamente bem encaminhada por Clastres. Entretanto, na rejeiçáo ao determinismo econômico, o autor aproxima-se de um outro tipo de determinismo: o político. Ele afirma:

É então a ruptura política - e não a mudança econômica - que é decisiva. A verdadeira revolução na proto-história da humanidade não é a do neolítico, uma vez que ela pode muito bem deixar intacta a antiga organização social, mas é a revolução política, essa aparição misteriosa, irreversível, mortal para as sociedades primitivas, o que conhecemos sob o nome de Estado. E se se quiser conservar os conceitos marxistas de infra-estrutura e de superestrutura, então talvez seja necessário aceitar reconhecer que a infra-estrutura é o político e que a superestrutura é o econômico (CLASTRES, 1990 [1974], p. 141).

A importância atribuída por Clastres à "ruptura política" e a negaçáo do papel das relaçóes de produçáo na transformaçáo social remetem a temas 
importantes do pensamento de Marx. Por um lado, coloca-se em questáo a relação entre (1) relaçōes de produção e forças produtivas; por outro, a ligação entre (2) base econômica e superestrutura jurídico-politica.

De início, é preciso ter em mente que as forças produtivas náo devem ser entendidas apenas no seu aspecto material, coisal. A primeira força produtiva é o próprio trabalho humano. O desenvolvimento das forças produtivas é, por isso, o desenvolvimento do próprio homem. Como tal, é um processo, em si, dialético, reflexivo. As relaçóes de produçáo não são capazes de determinar per si o grau de desenvolvimento das forças produtivas, mas é o tipo de relaçáo de produçáo que determina o impulso social (ou a ausência dele) para o desenvolvimento técnico das forças produtivas. Assim, pode-se dizer, por exemplo, que as formas de coerçáo extraeconômica pré-capitalistas náo criam o impulso ao aumento ilimitado das forças produtivas que é típico do capitalismo.

Por outro lado, o desenvolvimento das forças produtivas é condiçáo necessária para o desenvolvimento das relaçóes de produçáo, apesar de nunca ser condiçáo suficiente. Esse desenvolvimento das forças produtivas garante a possibilidade, mas não a necessidade, de determinadas relaçóes de produçáo. $\mathrm{O}$ desenvolvimento das forças produtivas é, pois, determinado pelas relaçóes de produçáo, mas a processualidade desse desenvolvimento pode, perfeitamente, criar as condiçóes objetivas necessárias para a transformaçáo dessas mesmas relaçóes de produção que a impulsionaram.

Mesmo sem transformar o progresso das forças produtivas no motor da História, é possível reconhecer uma tendência no seu desenvolvimento ${ }^{8} \mathrm{Ou}$ seja, pode ser reconhecida, ao longo da história humana, uma direçáo geral de desenvolvimento das forças de produçáo sem caráter determinista. Isso vai de encontro ao argumento de Clastres, que, ao tratar do nível de desenvolvimento técnico das sociedades primitivas, adota uma posição exageradamente rígida:

Não existe, portanto, hierarquia no campo da técnica [...] [pois] não existe escala abstrata pela qual se possam medir as "intensidades" tecnológicas: o equipamento técnico de uma sociedade não é diretamente comparável àquele de uma sociedade diferente, $\mathrm{e}$ de nada serve opor o fuzil ao arco (CLASTRES, 1990 [1974], p. 134, grifos do autor).

8 Assim como, analogamente, faz Clastres com relação ao desenvolvimento histórico das sociedades com Estado. 
O fato de náo se poder comparar o conteúdo da atividade produtiva de diferentes sociedades operando por lógicas diferentes e atendendo a necessidades sociais distintas náo impede que seja avaliado o grau de liberdade que um determinado padrăo tecnológico confere aos indivíduos no seu controle sobre si e sobre o meio em que se encontram, ou seja, sobre a natureza. De modo que, nesse quesito, as consideraçóes relativas ao desenvolvimento técnico devem ter por base o grau de desenvolvimento das potencialidades no devir homem do homem. É segundo esse critério objetivo (embora sempre relativo), do grau de liberdade frente ao meio e do desenvolvimento das potencialidades multiformes do homem, que se pode avaliar o grau de desenvolvimento das forças produtivas.

Em outro momento, quando trata a relaçáo entre o desenvolvimento técnico, a base econômica e a estrutura social total, Clastres afirma:

Que nos é ensinado por esse movimento do maior número de sociedades que passaram da caça à agricultura e pelo movimento inverso, de algumas outras, que, partindo da agricultura, chegaram à caça? É que isso parece efetivar-se sem que ocorra qualquer mudança na natureza da sociedade; que esta permanece idêntica a si mesma enquanto se transformam apenas as suas condições de existência material; que a revolução neolítica, se por um lado afetou consideravelmente, e sem dúvida facilitou, a vida material dos grupos humanos de então, por outro lado não acarreta de maneira automática uma perturbação da ordem social. Em outros termos, e no que tange às sociedades primitivas; a mudança ao nível do que o marxismo chama a infra-estrutura econômica não determina de modo algum o seu reflexo consequente, a superestrutura política, já que esta surge independente da sua base material (CLASTRES, 1990 [1974], p. 141, grifo nosso).

Clastres afirma, corretamente, que não existe uma ligação direta, mecânica, entre base e superestrutura, mas parece desconsiderar, nessa análise, que as diferentes esferas que formam a totalidade evoluem de forma desigual e, muitas vezes, contraditória. Os complexos que surgem como elementos relativamente autônomos na evoluçáo da socialidade (economia, política, linguagem, religiáo, direito etc.) desabrocham por necessidades e processos históricos específicos (por isso, constituem-se através de práticas específicas) e são regidos pela função mediadora que desempenham no processo global de reproduçáo das sociedades.

A socialização progressiva do ser humano torna inevitável o desenvolvimento desigual desses complexos, os quais, apesar de componentes de uma 
mesma totalidade, são heterogêneos entre si. A heterogeneidade é o próprio modo de manifestaçáo desses complexos, que se autonomizam relativamente para garantir sua própria eficácia como esferas ou momentos particulares do ser.

No que diz respeito à base econômica, referida por Clastres, deve-se dizer que esta náo é definida por aquilo que se produz, mas, antes, pela forma como se produz. Não é a caça ou a agricultura que, em si, definem um sistema econômico, mas o tipo de relaçáo que se estabelece entre os sujeitos na forma permitida pelas forças de produção disponíveis. Revoluçóes técnicas, além de náo conduzirem a resultados únicos, não implicam uma mudança imediata na lógica social, podendo apenas aprofundar uma determinada lógica vigente.

O nível de desenvolvimento das forças produtivas é apenas um dos fatores que compóem a totalidade. O grau de desenvolvimento das forças produtivas constrange as relaçóes de produçáo (não pode haver capitalismo, por exemplo, sem um nível técnico de produçáo compatível; não pode haver trabalho alienado sem a capacidade técnica de produçáo acima daquilo que o próprio produtor necessita para si), mas também é constrangido por elas (por exemplo, relaçóes de produçáo conservadoras impedem o desenvolvimento das forças produtivas). Trata-se, portanto, de uma relaçáo dialética. Isso, no interior, digamos, da base econômica. Mas, como isso se processa na relação dessa base com a superestrutura?

O trabalho alienado só pode existir na medida em que um sistema de poder estiver em vigor, submetendo os produtores, e, com isso, parece que a tese de Clastres a respeito da antecedência do Estado se confirma. Mas, um tal sistema de poder só está realmente em vigor quando o trabalho alienado efetivamente se processa, quando se conforma junto a uma estrutura de produçáo hierarquizada. $\mathrm{O}$ momento político age sobre o momento econômico, e ambos conformam uma estrutura orgânica, que determinará o desenvolvimento posterior tanto da forma política quanto do conteúdo social do sistema. $\mathrm{Na}$ medida em que se define uma relaçáo de produção hierarquizada ("eu sou proprietário e não você" ou "você trabalha para mim"), tem-se já, de imediato, o poder político em exercício, a forma mínima de Estado. Naturalmente, náo se trata de definir a prioridade cronológica dos fenômenos, mas o sentido ontológico que confere o conteúdo duradouro aos processos históricos. A partir disso, pode-se afirmar que as relaçooes de poder (quando existentes) são internas às relaçóes de produçáo da vida humana, não uma entidade à parte. 
A superestrutura política pode se modificar mantendo o tipo de produçáo (caça, agricultura etc.) inalterada dentro de certos limites, mas as relaçóes sociais que compóem a base econômica não estaráo isentas de mudança. Uma sociedade náo passa de um sistema escravista (em que os próprios homens sáo mercadorias) para um sistema de assalariamento sem uma profunda redefiniçáo do estatuto de cidadania, por exemplo. Quer dizer, sem uma profunda mudança na esfera política. Náo à toa, os exemplos de Clastres que apontam supostamente para uma autonomia plena da superestrutura política se referem apenas ao tipo de produçáo (caça $v s$. agricultura, nomadismo vs. sedentarismo), náo às relaçóes de produçáo em si.

É o tipo de relação de produçáo imposta (ou desejada), dado o grau de desenvolvimento das forças produtivas, que informa o poder político especificamente constituído, pois náo apenas o sistema econômico é historicamente determinado, mas também a forma como se estabelece o poder político na sociedade. Ou seja, o Estado também é sempre uma forma histórica particular.

Para um tipo determinado de hierarquia social operar, uma determinada organizaçáo econômica deve ser acomodada. O poder só existe em exercício. O Estado só se define quando recebe os tributos. Ele náo antecede o trabalho como esfera autônoma, pois é apenas quando existe o excedente que o Estado, enquanto categoria, se afirma. Ele depende das relaçóes de produção. E relaçóes de produção são, como se sugere, relaçóes sociais para a produção material da vida humana. Como relaçóes sociais, não podem ser puramente econômicas? Sáo atravessadas por determinaçóes políticas, as mesmas que se materializam (enquanto processo, contraditoriamente) numa determinada forma de entidade estatal concreta.

Apesar de essa concepção de Estado implicar que a evolução de uma autoridade pública coercitiva especializada gera necessariamente uma divisão entre produtores e apropriadores, ela não significa que a apropriação privada seja uma precondição necessária para o surgimento de tal autoridade. As duas se desenvolvem juntas, e um longo processo histórico às vezes intervém antes que a apropriação privada possa

9 Desse modo, ao se fazer referência à "base econômica", deve-se ter em mente seu caráter histórico e, consequentemente, que sua gênese e funcionamento se dão a partir da interação de várias esferas (econômica, política, ideológica etc.). Como produto dessa interação múltipla, a base econômica é assim denominada por dizer respeito ao conjunto de relações diretamente ligadas à da produção material: forças produtivas $e$ relações de produção. 
se diferenciar claramente do poder público. [...] Pode então ser enganadora a sugestão, frequentemente feita por marxistas em suas argumentações, de que existe uma sequência universal de desenvolvimento em que a classe precede o Estado ${ }^{10}$ (WOOD, 2003, p. 37).

Por isso, não faz sentido determinar quem nasce primeiro, se o Estado em sua figura mínima ou o excedente. Ambos surgem juntos. Afinal, não são as forças produtivas, nem as relaçóes de produçáo ou o Estado que determinam, isoladamente, a mudança social, mas a totalidade das relaçóes sociais. Não se trata de uma prioridade cronológica, mas da relaçáo de múltipla determinação que existe entre as esferas do ser social. A relação entre os complexos econômico e político deve ser vista, portanto, como de identidade e náo identidade. Um náo pode ser resumido ao outro, mas ambos interagem sempre na determinaçáo do momento concreto. É nesse ponto que reside a compreensáo dos dois momentos como uma unidade orgânica e dialética, tal como realiza Marx. O teor amplo, conclusivo e esclarecedor desse ponto justifica a extensa citação a seguir:

A forma econômica específica em que se suga mais-trabalho não pago dos produtores diretos determina a relação de dominação e servidão, tal como esta surge diretamente da própria produção e, por sua vez, retroage de forma determinante sobre ela. Mas nisso é que se baseia toda a estrutura da entidade comunitária autônoma, oriunda das próprias relações de produção e, com isso, ao mesmo tempo sua própria estrutura política peculiar. É sempre na relação direta dos proprietários das condições de produção com os produtores diretos [i.e., relações de produção] - relação da qual cada forma sempre corresponde naturalmente a determinada fase do desenvolvimento dos métodos de trabalho e, portanto, sua força produtiva social [i.e., forças produtivas] - que encontramos o segredo mais íntimo, o fundamento oculto de toda a construção social e, por conseguinte, da forma política das relações de soberania e de dependência, em suma, de cada forma específica de Estado. Isso não impede que a mesma base econômica - a mesma quanto às condições principais - possa, devido a inúmeras circunstâncias empíricas distintas, condições naturais, relações raciais, influências históricas externas etc., exibir infinitas variações e graduações em sua manifestação, que só podem ser entendidas de mediante análise dessas circunstâncias empiricamente dadas (MARX, 1985, p. 251-252, grifos nossos).

10 No caso de Clastres, essa afirmação, reconhecida por ele no marxismo vulgar, é combatida por meio da proposição inversa: a de que o Estado (político) precede a classe (econômica) - também unilateral teoricamente. 


\section{A gênese lógico-histórica do Estado}

Partindo das observaçóes precedentes, é possível esboçar, em linhas gerais, a gênese ontológica do Estado e, assim, qualificar o argumento de Clastres. No que diz respeito aos eventos que configuram a gênese do Estado, Clastres afirma que a lógica fechada da sociedade primitiva impede qualquer tentativa do chefe de se tornar senhor. Mesmo quando trata do ímpeto de liderança dos chefes guerreiros, cujo prestígio social depende do sucesso bélico potencialmente renovável, o autor afirma que a cobiça pelo poder é sempre interditada pela sociedade. Clastres sugere, entáo, que é a figura do profeta que, ao exortar os indivíduos contra a concentraçáo do poder no Estado, contraditoriamente assume, pelo poder da palavra, o governo sobre a sociedade.

O modelo de contradiçáo que explica o surgimento do poder de Estado a partir da negaçáo ao Estado parece condizente com os processos realmente contraditórios de desenvolvimento histórico do ser social. Afinal, é no processo de reproduçáo das sociedades como elas mesmas que surge, em algum ponto, o novo, o qual náo guarda necessariamente uma analogia direta com o estágio anterior. $O$ processo de mudança e emergência pode inclusive despontar através de um crescimento quantitativo, pois, além de certo ponto, o acúmulo na quantidade pode implicar mudança na qualidade.

Assim, o novo surge brotando do antigo que reproduzia a si mesmo sem qualquer intencionalidade consciente de mudança. É claro que o homem, progressivamente, se cerca dos meios de direçâo de seu próprio desenvolvimento, mas náo existe lei objetiva que possa ser imposta sem desvios à sociedade, pois a realidade concreta surge no processo, no devir.

A compreensão sobre a emergência do Estado, sugerida por Clastres, através da relação contraditória desencadeada pela própria negaçáo do Estado, pode ser enriquecida com um tratamento mais profundo do significado da individualidade e do papel que as categorias necessidade e casualidade desempenham como momentos recíprocos e imanentes ao processo histórico. Desse modo, é possível analisar o problema do ponto de vista da contínua complexificação da totalidade que é característica do desenvolvimento do ser social e projetar, em linhas, gerais o processo de surgimento do Estado.

De início, é preciso relativizar a hipótese de Clastres de que o líder guerreiro nunca pode fundar o Estado, dada a interdiçáo supostamente levantada pela 
própria sociedade primitiva. Ora, não existe lógica social totalmente imune ao agir humano. E a afirmaçáo de que uma lógica fechada não pode ser transformada vedaria até mesmo a contradiçáo em que Clastres deposita a possibilidade de surgimento do Estado (pelo poder da palavra dos profetas). Ou seja, por mais fechada que seja uma legalidade histórica, contradiçóes imanentes podem aparecer cumulativamente e conduzir a um processo de emergência do novo. Náo cabe aqui arrolar hipóteses sobre as possibilidades de êxito do líder guerreiro na sua busca pelo poder. Basta dizer que a negação peremptória dessas possibilidades está, na melhor das hipóteses, por ser demonstrada.

Dito isso, deve-se apontar como, no desenvolvimento da socialidade, a individualidade é capaz de surgir como fator passível de modificar a relaçáo própria do indivíduo com a espécie. Superando a relação natural de toda espécie com seu exemplar, do universal com o singular no campo biológico, o salto ontológico que configura, a partir do homem-ser-biológico o homem-ser-social, cria, necessariamente - fundado que está sobre o agir teleológico como elemento definidor do ser social -, o que pode ser chamado de generidade-não-mais-muda do homem (LUKÁCS, 2010). Ou seja, a pertinência consciente a um gênero que permite um agir intencional (por isso, "náo-mais-muda”) sobre esse próprio gênero.

É a partir da adaptação ativa do homem ao ambiente natural que o processo de superação da natureza biológica conduz à posição da sociedade como "segunda natureza", que se torna, nesse ponto, também manipulável, pois relaçáo de pertencimento do singular ao gênero não é a mesma no ser biológico e no ser social. Basta mencionar a mediação pela consciência da relaçáo entre indivíduo e gênero que está ausente no ser natural e é imanente ao ser social (náo importa em que grau).

No ser social, “[...] ocorre uma tendência de desenvolvimento muito importante do ponto de vista da generidade: a paulatina transformação da singularidade em individualidade." (LUKÁCS, 2010, p. 80). A singularidade, assim como a universalidade, é característica de todo ser. Mas, a individualidade só é possível na esfera social, pois só o processo de escolha teleológica (não importa com que grau de consciência) entre alternativas confere bases ontológicas para esse fenômeno pleno.

Com o desenvolvimento sócio-histórico da individualidade, os exemplares singulares passam a assumir posiçóes conscientes de conduçáo de seu 
próprio processo de desenvolvimento, tornando-se "imediatamente portadores e órgãos das modificaçóes na generidade” (LUKÁCS, 2010, p. 92). Quanto mais uma sociedade afasta as barreiras naturais (que, contudo, nunca são totalmente suprimidas), multiplicam-se para seus membros as possibilidades: as perguntas e as respostas.

A necessidade de decisão entre alternativas, intrínseca ao agir teleologicamente fundado, conduz a uma diferenciaçáo crescente dos tipos de reaçóes do ser social, que tem o trabalho (ontologicamente compreendido) como modelo de práxis. Inicialmente, essas reaçóes estáo imersas num "[...] contexto de tradiçóes tribais que atua quase que 'naturalmente'. Contudo, esse contexto precisa forçosamente adaptar-se e diferenciar-se frente às novas tarefas [necessidades] que sempre surgem.” (LUKÁCS, 2010, p. 108).

$\mathrm{Na}$ busca por compreender o momento a partir do qual o náo Estado se transforma em Estado, vê-se que a complexificação do agir humano que acompanha o despontar da individualidade como elemento fundamental do ser social ilumina a reflexão sobre a possibilidade de um chefe (ou um grupo), seja ele de cunho guerreiro ou religioso, reivindicar para si o controle sobre a sociedade em que, até entáo, está imerso ${ }^{11}$. Afinal, a atividade de regulaçáo mais abrangente no tempo e no espaço sobre uma sociedade pode, cumulativamente, criar elementos que permitam à individualidade do chefe subverter a lógica que o criou como simples meio para os fins da comunidade. Em um fragmento de uma carta escrita por Marx, pode-se corroborar a importância da individualidade no processo histórico. Trata-se de um comentário sobre os eventos da Comuna de Paris que ilustram bem o argumento:

A história universal seria muito cômoda se a luta só fosse assumida quando houvesse chances infalivelmente favoráveis. De outro lado, ela teria uma natureza muito mística se as 'casualidades' não desempenhassem nenhum papel. Essas casualidades naturalmente entram no curso geral do desenvolvimento e são compensadas por outras casualidades. Mas a aceleração e retardamento dependem grandemente dessas 'casualidades', entre as quais figura também o 'acaso' do caráter das pessoas que se encontram primeiro à frente do movimento (MARX apud LUKÁCS, 2010, p. 118).

II Sua imersão social, claro, é ineliminável, mas muda de caráter substantivamente. Como Estado, o chefe é agora imerso como poder que se apresenta externo. 
Reconhecer o acaso como momento do desenvolvimento significa também reafirmar o caráter processual da História. $\mathrm{O}$ acaso implica tanto a irredutibilidade do novo ao antigo como o caráter tendencial, jamais absoluto, das direçóes de desenvolvimento do ser. No interior da esfera social, a casualidade se afirma pelo fato de que "uma necessidade absoluta não existe de forma alguma. Ontologicamente, ela está sempre ligada a determinadas premissas" (LUKÁCS, 2010, p. 146). Premissas que também não têm caráter absoluto, pois o ser, como processo, é resultado da interaçáo de momentos em si heterogêneos. A causa que desencadeia concretamente um processo é ela mesma um processo que sintetiza diversos componentes e efeitos diferentes. "Uma sequência casual singular, considerada isoladamente, pode muito bem ser determinada por uma rigorosa causalidade, mas ela só pode se explicitar, na realidade, dentro de um complexo na qual a relaçáo dos eventos em questáo assume a forma da contingência." (LUKÁCS, 1979b, p. 98).

É a casualidade, potencializada pelo caráter alternativo do pôr teleológico na esfera social (continuamente mais abrangente), que confere o caráter previsível apenas post festum do desenvolvimento humano. É nesse sentido que o ser humano surge como um ser autofundado, produto de sua própria atividade.

$\mathrm{O}$ acaso surge no interior das necessidades objetivas (subordinadas ao ser-assim da realidade), concretizando, ontologicamente, as legalidades como possibilidades. Uma vez que não há lei absoluta ou desenvolvimento necessário em si na esfera social, pode-se apreciar a relaçáo entre as diferentes esferas desse nível do ser (economia e política, por exemplo) como reciprocamente condicionadas.

O reconhecimento de um momento predominante na interaçáo de complexos náo pode, porém, se confundir com nenhuma prioridade absolutizante no devir. "O ser consiste de interrelaçóes infinitas de complexos processuais, de constituição interna heterogênea, que tanto no detalhe quanto nas totalidades - relativas - produzem processo concretos irreversíveis." (LUKÁCS, 2010, p. 197-198). Irreversibilidade que configura novas possibilidades a partir (e por meio) do processo, a priori imprevisível, de interaçáo dos complexos.

O novo, portanto, náo surge de forma mecânica, determinada univocamente. E isso náo se reduz à gênese, aplicando-se também ao desdobramento 
dos processos. O surgimento do Estado não está inscrito como necessidade de desenvolvimento humano. Sua gênese e devir devem ser vistos como a concretizaçáo de possibilidades guiadas por tendências que apenas se efetivam a partir da contínua inter-relaçáo de complexos irredutíveis a uma causa única, o que supera a explicaçáo unilateral dos fenômenos sociais como exclusivamente políticos ou isoladamente econômicos.

Cada momento concreto é estabelecido a partir das condiçóes objetivas e do agir humano. $\mathrm{O}$ acaso éimanente ao processo, não uma falha de previsão. Nesse quadro, o desenvolvimento das forças produtivas aparece como condiçáo necessária para o desenvolvimento das relaçóes de produçáo, mas jamais como uma condiçáo suficiente. A concretização das possibilidades depende, em boa medida, do acaso do momento concreto, da múltipla coincidência de várias esferas, e o determinismo náo pode conviver com a casualidade - com o que se afirma uma compreensáo materialista do Estado ao mesmo tempo em que se reitera a afirmaçáo de que o marxismo autenticamente fundado se torna radicalmente estranho a qualquer princípio determinista.

\section{Considerações finais}

Para Marx, a prioridade ontológica da economia se sustenta como nível fundamental de existência do ser social, o que deriva da sua própria materialidade como ser. Ao mesmo tempo - e só dessa forma torna-se possível construir uma visão unitária e orgânica do mundo -, não é atribuída primazia absoluta a nenhum dos processos isolados. O poder é momento interno das relaçôes de (re)produçáo da vida humana; relaçóes a partir das quais emergem, ontologicamente (não cronologicamente), as estruturas concretas de poder. Estas, por sua vez, retroagem sobre as demais esferas do ser, modificando-as no curso do processo histórico. Trata-se, portanto, da totalidade como princípio metodológico, já que "o cerne estruturado do pensamento econômico de Marx se funda na concepção da determinaçáo recíproca das categorias que compóem o complexo do ser social" (VAISMAN; FORTES, 2010, p. 22-23).

As críticas de Clastres, se relativamente bem dirigidas ao marxismo vulgar, náo encontram abrigo na concepçáo original de Marx.

São, no fim das contas, a atuação e o desenvolvimento das forças produtivas que determinam o ser da sociedade, e é a contradição entre o desenvolvimento da forças 
produtivas e as relações de produção que, pondo em marcha a mudança social e a inovação, constitui a substância mesma e a lei da História. A teoria marxista da sociedade e da história é um determinismo econômico que afirma a prevalência da infraestrutura material (CLASTRES, 1976, p. 28).

Chamar a atenção para a individualidade e a casualidade como fatores fundamentais no processo social ajuda a colocar em primeiro plano o agir humano, amplamente compreendido, como o verdadeiro "motor da história", deixando claro (para além dos reducionismos, determinismos e mecanicismos, que em vários momentos foram associados ao pensamento de Marx) que "todos os fenômenos econômicos ou 'sociológicos', derivam das relaçóes sociais entre os homens" (LUKÁCS apud AUGUSTO, 2010, p. 18).

Marcar as diferenças e insuficiências de um construto teórico náo significa deixar de reconhecer seus méritos. Para além das incompatibilidades com a perspectiva marxiana, que diz Clastres, afinal? Que uma sociedade efetivamente livre só pode se desenvolver para além do Estado, para a superação da alienação do Estado e de todas as esferas que escapam ao controle da sociedade como condiçáo para uma autêntica autodeterminaçáo humana - para o humano como único critério do desenvolvimento do homem. Tese muito próxima, em sua substância, da proposiçáo marxiana do comunismo como superaçáo das classes e do Estado.

\section{Referências}

AUGUSTO, A. G. O materialismo de Lukács e a crítica ao determinismo. In: IV Coloquio internacional teoría crítica y marxismo occidental - el pensamiento tardio de György Lukács. Buenos Aires: 2010. Disponível em: <http://pt.scribd.com/doc/50893943/o-materialismo-deLukacs-e-a-critica-ao-determinismo-revisao>. Acesso em: 01 abr. 2014.

CHASIN, J. Marx - estatuto ontológico e resoluçáo metodológica (posfácio). In: TEIXEIRA, F. J. S. Pensando com Marx: uma leitura crítico-comentada de O capital. Sáo Paulo: Ensaio, 1995.

CLASTRES, P. Préface. In: SAHLINS, M. Âge de Pierre, âge d'abondance. L'économie des sociétés primitives. Paris: Éditions Gallimard, 1976.

A sociedade contra o Estado. São Paulo: Francisco Alves, 1990 [1974].

LUKÁCS, G. Ontologia do ser social: princípios ontológicos fundamentais de Marx. Sáo Paulo: Ciências Humanas, 1979a. 
Ontologia do ser social: A falsa e a verdadeira ontologia de Hegel. São Paulo: Ciências Humanas, 1979b.

Prolegômenos para uma ontologia do ser social. São Paulo: Boitempo, 2010.

MARX, K. Elementos fundamentales para la crítica de la economía política (Grundrisse 18571858). México, DF: Siglo XXI, 2009. v. 2.

O capital. São Paulo: Abril Cultural, 1996. 1. 1. t. 2.

O capital. Sáo Paulo: Abril Cultural, 1985. 1. 3.

MARX, K.; ENGELS, F. A ideologia alemá. Sáo Paulo: Boitempo, 2007.

VAISMAN, E. ; FORTES, R. V. Apresentação. In: LUKÁCS, G. Prolegômenos para uma ontologia do ser social. Sáo Paulo: Boitempo, 2010.

WOOD, E. Democracia contra capitalismo. São Paulo: Boitempo, 2003.

Recebido em: 19/11/2012

Aprovado em: 22/10/2013

\section{For a critical ontology of the State and politics: a debate between Marx and Clastres}

\section{Abstract}

The paper analyses the main theoretical elements in the work of the ethnologist Pierre Clastres concerning the constitution of the political sphere. In attempt to reinforce a critical perspective about the State, the analyse will be done within a marxian theoretical frame, procedure that appears to be as fruitfull for the clastrian ethnology as for a marxist theory of the State. The consideration departs from the identification of an ontonegative conception of the State present both in Clastres's considerations as in Marx's social theory. Gÿogy Lukács's lasts works will be used as reference, specially in its considerations about the founding categories of the social being, from which the author develops important elements for a materialist ontology.

Keywords: State. Economy. Ontology. 
